\title{
Sovereignty and Responsibility in Global Refugee Protection and Humanitarian Intervention in the $21^{\text {st }}$ Century
}

\author{
Nurul Azizah Zayzda ${ }^{1}$
}

\begin{abstract}
This paper is concerned on the interlinking politics in refugee protection and humanitarian intervention as well as the trends of developments in refugee protection that has been undermined especially in a number of developed countries. In international protections, sovereignty always appear as a major debate since protections involve interference by external forces (in humanitarian intervention) or arrivals of external populations (in refugee protection). The sense of responsibility, referring to the political willingness to provide protection or assistance have been influenced by the understanding on sovereignty. The aim of this paper is to explain how the concepts have been contested through practices of refugee protection and responsibility to protect. In order to demonstrate the issue of sovereignty and responsibility at hand, this paper departs from the discussion of the two concepts as found in the historical accounts of the protection regimes which are refugee protection and the humanitarian intervention. The following part discusses the recent development of the two regimes of international protection. Within each part, the notion of sovereignty and responsibility are assessed from the practices of the two regimes. From the discussion, it can be understood that the ways these concepts were produced and contested reflect the presence of a bigger framework namely politics of human rights which tend to be dominated by the interests of big political power.
\end{abstract}

Keywords: sovereignty, responsibility, human rights, refugee protection, humanitarian intervention, responsibility to protect.

\begin{abstract}
Abstrak
Tulisan ini ingin mendalami keterkaitan politik HAM dalam perkembangan perlindungan pengungsi lintas batas dan intervensi kemanusiaan serta dampaknya berupa kecenderungan membatasi laju pengungsi di sejumlah negara maju. Dalam perlindungan internasional, kedaulatan selalu muncul sebagai debat utama karena perlindungan masyarakat terdampak melibatkan keterlibatan kekuatan/militer eksternal (dalam intervensi kemanusiaan) atau kedatangan populasi eksternal (dalam perlindungan pengungsi). Rasa tanggung jawab, merujuk kepada kemauan politis untuk memberikan perlindungan atau bantuan, dipengaruhi oleh bagaimana kedaulatan ini dipahami. Tujuan tulisan ini adalah menjelaskan bagaimana kedaulatan dan tanggung jawab dikontestasi melalui praktek perlindungan pengungsi lintas batas dan intervensi kemanusiaan. Untuk menunjukkan isu kedaulatan dan tanggung jawab, tulisan ini berangkat dari pembahasan mengenai kedua konsep yang terdapat dalam sejarah dari rezim perlindungan pengungsi lintas batas dan intervensi kemanusiaan. Bagian berikutnya membahas perkembangan dari dua rezim internasional perlindungan bagi masyarakat terdampak. Di bagian ini, gagasan kedaulatan dan tanggung jawab harus dipelajari dari praktek-praktek dua rezim perlindungan internasional tersebut. Dari diskusi yang ada, dapat dipahami bahwa konsep yang diproduksi dan dikontestasi merupakan bagian dari kerangka yang lebih besar yaitu politik HAM yang cenderung masih didominasi oleh kepentingan kelompok negara dengan kekuatan politik yang besar.
\end{abstract}

Kata-Kata Kunci: kedaulatan, tanggung jawab, politik HAM, perlindungan pengungsi lintas batas, intervensi kemanusiaan.

\footnotetext{
${ }^{1}$ Penulis adalah dosen Jurusan HI, FISIP Universitas Jenderal Soedirman. Email: zayzda.nurulazizah@gmail.com
} 


\section{Introduction}

Refugee protection and the humanitarian intervention are two different areas in the field of protection of human rights. Both are major issues in the field; humanitarian intervention has been practiced post-World War II and recently gave birth to responsibility to protect; while refugee protection was formerly a political tools of the West during the Cold War. Whether it is humanitarian intervention and refugee protection regime are highly concerned with vulnerable and powerless people in the places of conflicts or where the governments are found to be failed in protecting their own citizens. Furthermore, humanitarian intervention and refugee protection regime are concerned on the basic human rights of the people. The difference is, while refugee protection regime talks about the people who flee from their countries of origin where violent conflict erupts, the humanitarian intervention is more concerned on protecting the people inside the countries where the affected people reside. And finally, the development in both humanitarian intervention and refugee protection regime have been driven highly by the big power in international relations, namely the Western countries through the United Nations.
Due to the politics driving the two regimes, many have argued that the development of refugee protection regime and humanitarian intervention are not entirely clear cut. Loescher, et. al., (2008), for example, highlight that the end of world war has changed the way Western countries approach the refugee issue by placing restrictions on entry of the people who flee to their country, or also commonly written as asylum seekers. ${ }^{2}$ While during Cold War these big countries have been the prominent advocates for refugee protection, the end of Cold War marked by the emerging globalization which pushed more mass movement towards the West has witnessed a seachange. Refugees influx increased significantly but they were not as welcomed as they were in the past because they began to be understood as the burden for the host state, and the Western countries began to impose restrictive entry measures to immigrants and consequently, to the asylum seekers (Haddad, 2008: 166).

The connection between refugee protection and humanitarian intervention was found in the way that intervention is required to "reduce the likelihood of massive refugees flow across borders" (Loescher, et. al., 2008: 54). It was understood that humanitarian intervention was needed to help bring the

\footnotetext{
${ }^{2}$ Refugees and asylum seekers are basically the same people. The 1951 Convention Related to the Status of Refugees basically only use the terminology 'refugee'. Asylum seekers is not mentioned in the agreement document. The distinction between the two of them is the further consequence of the use of UNHCR guidelines on protection. UNHCR rules that not every single person fleeing a country and ask for asylum can be granted protection. Only the people who are 'well-founded' to be threatened by persecutions are granted protection. Only when they pass the assessments are they called refugees. The others who have not yet passed the process are addressed as "asylum seekers.
} 
conflict to an end or to keep a region stabile, so that people will not leave to find asylum. The terminologies like internally displaced persons, peacekeeping operations or peacemaking operations which emerged after the Cold War were central in this to keep the affected or potentially affected people stay at their homes (Loescher, et. al., 2008; Ferris, 2011). Although this linkage can be regarded as one of solutions for the global crisis of refugee, it will be problematic if it results in the restrictions of refugee entry to states outside their home and leave the refugees stateless.

With the available linkage, the refugee protection and the humanitarian intervention can be understood as parts of a bigger picture of politics of human rights. Politics of human rights is to be differed from the philosophy of human rights. While philosophy is about the meaning, the fundamental and reasoning of human rights, politics of human rights is about how the definition of human rights is made and institutionalized (Ingram, 2008: 402). This is to say that the present understanding on human rights is a result of political struggle. An early important work on human rights can be found in the works of Hannah Arendt. From her observation in the situation during Cold War II she came to the conclusion that right to have rights, which is the rights of those who are denied, can only be met with act of politics (Isaac, 1996: 67). The history of the politics has demonstrated that in the heart of human rights, thus, is the idea about 'protection', referring to protecting the rights of those who are denied. Ferris (2011) notes that there are different yet interconnected developments of fields of protection originated from Europe namely international human rights law, refugee law, international humanitarian law which are meant to institutionalize the accepted definition of human rights and protect the vulnerable people (Ferris, 2011: 59).

The international humanitarian law talks about protection of people in conflicting areas, hence it endorses humanitarian intervention and refugee law is about protection of people who move across border, hence it requires international solidarity. Considering that the refugee protection and humanitarian intervention deal with crossborder policies, the refugee protection and humanitarian intervention here are marked by the grasp of two intertwining concepts namely sovereignty and responsibility.

The aim of this paper is to explain how the concepts have been contested through practices of refugee protection and humanitarian intervention. The first concept, sovereignty, here refers to two definitions; firstly, the Westphalian concept which recognizes the independence of a nation-state from external influence, the government's exercise of power within the nation-states boundary and its exclusionary nature; secondly, the concept of sovereignty which assumes state is responsible for its domestic issue and citizens (Keohane, 2003: 282; Isaac, 
1996: 68; Betts, 2009: 43). Thus, the concept of sovereignty implies two understandings, first one is that states are autonomous, and should be free from others' interferences, and the second one is that they are responsible of the citizens inside their territory.

The second concept is the concept of responsibility, which derives from the practices of protection themselves. In this paper, responsibility is defined as a set of political willingness and international policies carried out by international institutions as well as individual states related to the humanitarian crisis in refugee and conflicts. Therefore, it talks about international policy, international law as well as individual states' policies and legal framework in pursuing the aims of protection. The question being addressed by this concept includes to what extent international institutions protect the rights of refugee and people affected by conflicts and how do individual states abide with international law, or instead, affect international law with regard of protection. The terminology responsibility has been attached to refugee protection, where responsibility implies the states' policy to accept asylum seekers and refugees with respect of the Refugee Convention, and to humanitarian intervention which then gave birth to responsibility to protect.

The subsequent part of this paper is divided into several parts. The next part is focused on the highlights in early development of refugee protection regime and humanitarian intervention. The next part discusses the recent development of the two regimes and is completed by case studies on refugee protection and humanitarian intervention, which demonstrates the trend in the $21^{\text {st }}$ century, and analysis how the notion of sovereignty and responsibility were contested over times.

\section{Earlier Development of International Protection}

This part argues that the politics of human rights during Cold War, comprises of attempts to establish a "moral legitimacy" of particular groups (Evans, 2001: 14). By moral legitimacy, it means that the legitimacy of the Western Bloc and its liberal democracy ideas during Cold War period in world politics. By presenting themselves with humanitarian ideas with concern on human life and rights, they are advantaged in the war against communism. Consequently, the post-Cold War period has witnessed different trends in the international protection regime.

The refugee protection regime sets back to the World War period, where refugee protection was regulated by the International Refugee Organization in 1947. From the very beginning of its creation, the terminology of "refugee" refers to particular group of people. In this period, refugees are the victims of war and the Jewish people. The end of World War and the erection of United Nations marked a new age of refugee regime. The following 
tension with the Eastern Bloc shifts the meaning of refugees into "people who have well-founded fear of persecution". The use of terminology "persecution", points directly to the communism in the Soviet Union. In other words, refugee protection in this period is an integral part of antagonizing the Eastern Bloc regime (Loescher, et. al., 2008: 14-15). ${ }^{4}$

Haddad (2008) and Loescher, et. al. (2008) elaborates further the outcome of this sort of politics of refugee during the period. Firstly, refugee protection was highly European-centric since the focus of the politics was the Soviet Union. The attention was paid mainly to the people fleeing from the Soviet Union to the Eastern Europe. Whereas in fact, uprising and internal conflicts also took place elsewhere in the world and refugee influx were not the only one in the Eastern Europe. Secondly, outside the European world, only the cases related directly to communism were given sufficient attention by the international community or the United Nations which were basically dominated by the Western power. For instance is the refugee mass displacement from Indo-China countries which underwent the Proxy-War (Haddad, 2008: 151; Loescher, et.al., 2008: 53).

In addition to those outcomes, it can also be implied that refugee protection during this early development affirms the rhetoric of refugee protection as a state's rights (to determine who or when to give protection) as opposite to the refugee's rights (to be protected by the international community when their own government are failed). Nowhere in the Refugee Convention was mentioned that all states are obliged to provide protection to the refugees. The only thing being guaranteed is to seek asylum to other countries (DIMIA, 2001: 128).

This rhetoric becomes a legacy in the following period of world politics. When the Soviet Union collapsed and Western Liberal Democracy made the global politics, refugee influx increased instead of decreased. Many factors contribute to this emergency. Not only that opened conflicts now take place in many parts of the world, but also the concern is no longer only about communism. Furthermore, globalization has provided the space, tools and endorsement for people to move across borders, not excluding the people who need to flee from persecution.

The Western developed countries however, with the fall of communism, found that refugee emergency had passed. The new or proceeding wave of refugee movement are not part of the normal protection regime. Restrictive measures began to be imposed; the practice of detention centers, long asylum process, the employment of temporary

\footnotetext{
${ }^{3}$ This is the definition of refugees in the 1951 Convention Related to the Status of Refugees.

${ }^{4}$ See also Zayzda, et. al.(2015).
} 
protection and in general the "visa regime" which effectively limits the number of protection being granted in a country. ${ }^{5}$

Humanitarian intervention began to be a foremost tool to make sure that mass movement of people towards the developed countries is limited (Loescher, et. al., 2008: 54). Humanitarian intervention itself originated from the liberalist's thought on democracy and the need to uphold it everywhere in the world (Farer, 2003: 56). Nevertheless, it was a basic that the foundation of $\mathrm{UN}$ is the principle of non-intervention. This was particularly the concern of the newly independent countries who were resistant against the Western intervention in their domestic affairs. Thus, during the period of Cold War, interventionism was not endorsed by UN, although in fact, a number of interventions were carried out by several western countries. Amongst them are the intervention in Suez by the Anglo-French in 1956, in Hungary and Afghanistan respectively in 1956 and 1979 by the Soviet, and Grenada and Panama in 1983 led by the US (Roberts, 2004: 71-88). Following the end of Cold War, UN began to engage in a number of humanitarian interventions encompassing intervention in Northern Iraq (1991), Bosnia and Herzegovina (1992-5), Somalia (1992-3), Rwanda (1994), Haiti (1994), Albania (1997), Sierra Leone (1997-2000), Kosovo (1998-9), and East Timor (1999) (Roberts, 2004: 81).
In addition to the objection of most developing countries on the principle of nonintervention is the bias from the proponents of the humanitarian intervention themselves. Roberts notes that double standard is found in the practice of humanitarian intervention, resulting in the 'selective' nature of humanitarian intervention. Many argues that this is rooted in the dominance of the US in UN decision making (Roberts, 2004: 88). This bias of particular actor's interest caused a failure in humanitarian intervention, for example in the case of Rwanda where international society did not take action to protect the citizens of Rwanda from the massacre. The debates on this issue then gave birth to the concept of responsibility to protect.

Farer posits that the existing link between humanitarian intervention and refugee issue lies on the advocacy for humanitarian intervention which according to various opinions, is urgent matter in developed countries since people seeking asylum in their countries may affect their national interest (Farer, 2003: 59). By intervening in ending conflict and providing humanitarian aids, it will make possible lesser refugee inflow.

The initial development of refugee protection and humanitarian intervention expresses the politics of human rights and the attached debate on sovereignty. There has been a strong argumentation on the concept of

\footnotetext{
${ }^{5}$ Visa regime refers to the use of visa as requirement of legal entry to a country. See also Gibney (2006).
} 
sovereignty which justifies humanitarian intervention since early 1990s until it was transformed into the responsibility to protect in 2000s. The objection against humanitarian intervention mainly concerns its tension with the principle of sovereignty (Welsh, 2004a: 53). Nevertheless, the proponents of humanitarian intervention found that it does not really antagonize sovereignty vs human rights, it is the other way around, as sovereignty means a government is responsible to its own citizens (Welsh, 2004b: 177). Responsibility, in the cases of humanitarian intervention is regarded as global responsibility to protect the human rights everywhere in the world.

Compared to these, the debates on sovereignty in the refugee protection has been more subtle. The existence of Refugee Convention and UNHCR have given the pathways for refugees to move across border, but in the practice, it was restricted by the national policy of the countries of asylum/ destination of refugees. Although protection is also regulated as global responsibility, the practice has been more complex, with responsibility has been undermined by the interests of individual states.

\section{Assessments in Recent Situations}

\section{Refugee Crisis and Response in Developed} Countries

After Cold-War ended, refugee outflow did not end. UNHCR (2012) posits that the refugee crisis in this $21^{\text {st }}$ century is far more complex than those before with the various source of conflicts and actors generating violence inside the country (UNHCR, 2012). In 2006, there were a total of 9,2 millions of refugees and over 19 million people of concerns of UNHCR (UNHCR, 2006). The number of refugees increased so there were 10,5 million refugees in 2011 with half of them were from Iraq, Afghanistan and Somalia (UNHCR, 2012). The war in Syria has caused a significant increase in refugees, which António Guterres, UN Commisioner for Refugees called this a "paradigm shift" where new approach in responding the crisis is needed (UNHCR, 2015a). As per the end of December 2014, there had been already 19,5 millions of refugees worldwide (UNHCR, 2015a).

With the high number of refugees, larger part of them have been hosted in developing/less-developed countries. In 2012, the top host-country for refugees were Pakistan (1.6 million), Iran $(868,200)$ and Kenya $(565,000)$, while Germany made the only Western countries with Germany 589,700 settled in that year (UNHCR, 2012: 2). The recent Syrian cases have made the neighbouring countries, Turkey, Lebanon, Iran, Jordan and Ethiopia the host with largest number of refugees. Increase of number of refugees seeking asylum to developed countries in Europe and America also occurred in 2014 (UNHCR, 2015b). 
Nevertheless, most of worldwide refugees - around 80 per cent of them - have been hosted mostly in developing countries (UNHCR, 2015a). Aside from geographical factor where developing countries are typically the neighbouring countries of the conflicting countries who then trigger refugee influx, other factor can be taken into account. Since the early post-Cold War period, refugee issues have generally been separated from human rights agenda, as explained by UNHCR (1995) in its publication "In Search of Solutions". In many parts of the world where Refugee Convention are signed and ratified, asylum seeking process are undermined by strict immigration control. While refugee is highly a human rights issue, linking the refugee's aspect of arrival to immigration control shifts it to sovereignty issue. Gibney (2004) explains the imminence of perspective that regards refugees as threats, where states are anxious about the volume, character and anonymity of refugees coming to their place (Gibney, 2004: 255).

Australia is one of the countries that exemplifies this kind of perspective in creating asylum policies. Several measures being used in these countries comprise of strict screening during entry, detention policy (mandatory detention in Australia for several periods), deportation policy, and temporary protection (Loescher, et. al., 2008; Castles and Davidson, 2000; Gibney, 2006; Goodwin-Gill and
McAdam, 2007; Crisp, 2010). As to demonstrate the grasp of sovereignty and responsibility in refugee protection issue by a developed country, Australia case is discussed in further detail here.

Australia has experienced various changes in its asylum policy during 2000s involving the administration of John Howard, Kevin Rudd, Julia Gillard and Tony Abbot. In the early 1990s, Australia came up with a new policy that has been maintained until almost the next two decades; the mandatory detention policy. The mandatory detention policy rules that every person arriving in Australia in illegal manner, without travel documents, identities, or illegal means of transportation, will be detained in detention centres. In 1999 , still in Paul Keating administration, temporary protection visa was enacted for the first time. Temporary protection visa was a form of refugee status given to particular group of asylum seekers, ones arriving in illegal manner. In the same year, a regulation in immigration arena was made to penalise people smuggler. Although penalty for people smugglers are formally separated from policy on asylum seekers, it effects those who are in no choice but travelling with the smugglers.

When Kevin Rudd came into office for the first time in 2007, his administration made a transformation of Australian asylum policy. First, Australia closed down the offshore processing centre in Nauru and Manus Island, 
meaning that asylum seekers wishing to seek protection in Australia will be processed there. Next in 2008, the government concluded the temporary protection visa program. In addition to that, mandatory detention was not imposed against all asylum seekers arriving illegally anymore, only for most complex cases.

The changes made during Rudd's administration was reversed again when he was replaced by Julia Gillard. First, an "asylum seekers exchange" arrangement was made with the Malaysian government as a "burden sharing" responsibility (DIAC, 2012). Furthermore, Australia began to perform some campaigns on discouraging asylum seekers coming to Australia. The first was the "No Advantage" campaign, stating that:

"Australia by Boat? No Advantage. Process you in Nauru or Papua New Guinea no faster than if you were in refugee camp. Provide no family member sponsorship concessions. Offer no certainty of resettlement in Australia."

In 2013, Rudd replaces Gillard again, and the new government spread the new campaign, with a tagline "If you come here by boat without visa, you won't be settled in Australia." Abbot's administration threw another campaign in 2014, this time, the tagline is, "No way, you will not make Australia home. The Australian Government has introduced the toughest border protection measures ever. Think again before you waste your money, people smugglers are lying."
It was further made clear in the website of the Australian Customs and Border Protection Service website, in an article titled "Counter People Smuggling Communication, Operate Sovereign Border":

Asylum seekers who travel by boat without a visa will not end up in Australia. The rules apply to everyone; families, children, unaccompanied children, educated and skilled. There are no exceptions. Australia is serious about protecting its borders and will stop anyone who attempts to come illegally by boat. (Australian Customs and Border Protection Service, 2014).

This Operate Sovereign Border tells the public the danger imposed by smuggling; a danger to asylum seekers and to state's sovereignty. The sense of "safety" of asylum seekers is made to affirm the real issue; sovereignty. This is also the case for the preceding policies. Starting from the mandatory detention, temporary protection visa to the processing center abroad. Both the mandatory detention and temporary protection visa are imposed against one's ability to provide travel documents or to travel by authorised transportations. This kind of policy tends to neglect the fact that asylum seekers are commonly in extremely difficult situation that they have no much choice to travel or simply unable to apply for visa due to both financial and security issue at home. Instead, state border is in the heart of these policies, 
and asylum seekers, no matter how emergency, how incapable, vulnerable they are, shall abide this rule about state border.

The experience in Australia depicts the normal asylum policy which has been linked with immigration policy. Although not all developed countries apply the similarly strict policy, limitation in asylum seeking is innate in immigration policy, only in varying scales. To conclude, the politics of refugee protection in the $21^{\text {st }}$ century is marked by the common tendency to limit the mobility of asylum seekers attempting to enter a country. Herein the visa regime lays the foundation as the foremost law in migration, overruling the international refugee law itself. Understanding that in most countries refugee issue is automatically linked to immigration issue, it has always been complicated to create a refugee protection regime that actually speaks about refugee's rights and not the state's rights, or in the words of Nyers (2003), asylum policy "is not just a humanitarian determination but a moment when sovereign state (re)found its claim to monopolize the political" (Nyers, 2003: 1071).

Together with humanitarian intervention, the refugee protection marks a stronger grasp on the notion of sovereignty as autonomy from the external. In this sense, the developed states tend to see that the same sense of sovereignty is not applicable in the conflicting countries or where persecutions take place, as seen in the development of humanitarian intervention.

\section{Responsibility to Protect as Sovereignty}

Responsibility to Protect is the face of interventionism in the $21^{\text {st }}$ century. According to Evans and Sahnoun (2002), the concept of Responsibility to Protect was created in early 2000s due to the concern that the state should be the first and foremost actor of protection. The idea of responsibility as replacement of intervention appeared after the series of interventions during 1990s in Liberia (1990), Northern Iraq (1991), Haiti (1994), Sierra Leone (1997) and East Timor (1999). The debates around humanitarian intervention mainly argues the rights of outsiders to intervene with the internal issues of a sovereign state. On the other side it has been founded that intervention frequently occur only when it deals with the interests of the powerful states. It resulted in inconsistency of implementation of humanitarian intervention (Brown, 2008). The Rwandan case was one of the cases that was mainly highlighted when talking about interest and inaction.

Here, international community found the need to reinvent the strict arrangement on humanitarian intervention and how it should accommodate the sovereignty of the nationstates. It was begun by Kofi Annan's comment in 1999 on the notion of absolute state sovereignty that was under challenge. Having been criticized for crossing other states' sovereign borders and its first world country 
bias, it was believed that state sovereignty in Westphalian manner should be brought back.

In 2001, International Commission on Intervention and State Sovereignty (ICISS) introduced the concept of $\mathrm{R} 2 \mathrm{P}$. The concept does not diminish the humanitarian intervention. Instead, intervention is more justified more than ever now. The two concepts of sovereignty are reaffirmed; on one side, it is something that every nation-state is made of and thus should be respected by every other nation-state; and on the other side, it means that every nation-state should be responsible of their own citizens if they want to be called sovereign, hence "sovereignty as responsibility". The new age of humanitarian intervention arranges that intervention by external force is only lawful when the government of a nation-state is found to fail the protection of their own citizens. The rhetoric being delivered here is that humanitarian intervention is no longer about the rights to intervene, but the responsibility (of the global community) to protect (Nanda, 2013:5). The responsibilities consist of responsibility to prevent conflict through diplomacy, economic means and even military force; responsibility to react preceded by several other precautions or the failure of prevention which justify a sanction, persecution or military intervention; and responsibility to rebuild after the conflict or military intervention ended (Nanda, 2013: 6-7; Brown, 2008: 13).
In the 2005 World Summit, the principles of responsibility to protect was endorsed and included in the UN World Summit Outcome documents. The principle was then referred in the Security Council Resolution 1674 about the protection of civilians in armed conflict and referred again in Sudan. This principle however was objected in the case of Myanmar after the Nargis cyclone. The principles of responsibility to protect was firstly come into use in the adoption of UN Resolution 1973 which gave authorization for military intervention of UN Security Council member states in Libya where the Gaddafi government attacked its own citizens. It was preceded by the adoption of UN Resolution 1970 in February 2011 which condemned the Libyan government. The military intervention was carried out from March 2011 by NATO and concluded in October 2011 when Gaddafi was overthrown (Nanda, 2013: 9-13).

The ICISS proposal of the "sovereignty as responsibility" principle as the foundation of responsibility to protect is a result of debates in humanitarian intervention where developing countries tend to object humanitarian intervention on the basis that it violates their sovereignty. Despite offering a sort of 'middle way' in the sovereignty debate, the direction of this development is reaffirming the legitimacy of interventions by external actors (Brown, 2008: 8). This is rooted in the liberal claim of human rights which then 
justifies the humanitarian intervention to end the violation of human rights and build democracy where it has not been built.

From the discussion above, the ways sovereignty has been grasped in varying manners across protection regime. The common trend in the refugee protection is the reproduction of discourse of sovereignty as autonomy through restriction of entry. On the other hand, responsibility to protect symbolizes sovereignty as responsibility, so that when responsibility was not achieved, intervention is allowed. Generally, intervention is carried out by the Western developed countries. This demonstrates what Evans (2001) calls the 'politics of human rights'. The politics of human rights is marked the role of US in shaping the moral direction of human rights in the world following the end of Second World War. The 'human rights' as we know it today is actually a very "particular conception of human rights that sought to legitimate its (US) own interests and those of capital" (Evans, 2001: 14). Consequently, the trajectory of the protection regime follow the accepted definition of human rights.

It has been illustrated that the development of refugee protection and responsibility to protect have not been solely a human rights issue; it is also about whose interests are being served or threatened along the way of the protections. Fitted with the liberal claim of human rights and democracy, sovereignty are sometimes perceived as matter of autonomy, but in other cases, they are seen as responsibility. The result is, refugees are always regarded as external alien population who are problematic to states' sovereignty, while the implementation of humanitarian interventions depend so much on the interest of the powerful states.

\section{Conclusion}

The article delivers a pre-study to further studies on both refugee protection and humanitarian intervention. By examining the development of the two regimes in the last two decades, it was found that the discourse of sovereignty have been produced in different manners and there has been partition between the developed and developing counties. The humanitarian intervention was championed by the developed western countries with their liberal discourse on civil and political rights which drive them to use intervention to ensure the protection of human rights in places where it is not protected the way they believe it has to. The objection with sovereignty reasons come from the developing countries who find themselves infringed by external forces. In refugee protection, objections with sovereignty reasons come from the host states, both developed and developing ones. Therefore, the developed countries who in global politics possess the power to determine the direction of protection regime, demonstrate different grasp of sovereignty in the two cases. 
Under the framework of politics of human rights, the recent politics of refugee protection and responsibility to protect show that the moral claim of responsibility to protect demand the human rights protection from home. Thus, when state is unable or unwilling, it is justified for international society to help protecting them through intervention. While this is purposed to "help", the other intention to prevent refugee influx has negative effects on refugee protection. It is rooted in the grasped territorial recognition so that citizens, despite fear of life threatening circumstances at home, normally belong to their own country. That causes the common restricted manner in accepting entries of refugees. On the other hand, humanitarian intervention suffers from different implementation, relying on the interests of the Western developed countries who constitute the major political power. This paper suggests that further study needs to be made to measure the extent to which humanitarian intervention/responsibility to protect has actually helped solving the local human rights crisis. Also, it is more important now than ever to figure the possible protection scheme in the future that lies more on protecting the human rights of the affected population and less about preventing their mass entry to other countries. 


\section{References}

Australian Customs and Border Protection Service. (2014). Counter People Smuggling Communication, Operate Sovereign Border. Retrieved November 1, 2014 from http:// www.customs.gov.au/site/Translations/english.asp.

Benhabib, S. (2011). Dignity in Adversity: Human Right in Troubled Times. Cambridge: Polity Press.

Betts, A. (2009). Forced Migration and Global Politics. Chichester: Wiley-Blackwell

Black, J. K. (2009). The Politics of Human Rights Protection: Moving Intervention Upstream with Impact Assessment. Plymouth: Rowman and Littlefield Publisher, Inc.

Brown, A. (2008). Reinventing Humanitarian Intervention: Two Cheers for the Responsibility to Protect? House of Commons Library Research Paper, 8/55.

Castles, S. and Davidson, A. (2000). Citizenship and Migration : Globalization and The Politics of Belonging. Basingstoke : Palgrave.

Crisp, J. (2010). A new asylum paradigm? Globalization, Migration and the Uncertain Future of the International Refugee Regime. In Vertovec, S. (Ed.). Migration, Vol. IV (pp. 129-141). London: Routledge.

Department of Immigration and Citizenship. (2012a). By Boat, No Advantage. Retrieved, July 8, 2013. http://www.immi.gov.au/managing-australias-borders/border-security/irregularentry/no-people-smuggling/_pdf/poster-english.pdf.

Department of Immigration and Citizenship. (2013a). If you come here by boat without a visa you won't be settled in Australia. Retrieved August 2, 2013 from http://www.immi.gov.au/ visas/humanitarian/novisa/pressad.pdf.

Department of Immigration and Multicultural and Indigenous Affairs. (2001a). Article 31- 
Refugees Unlawfully in the Country of Refuge: An Australian Perspective. Canberra: DIMIA.

Evans, T. (2005). The Politics of Human Rights: A Global Perspective. London: Pluto Press.

Farer, T. J. (2003). "Humanitarian Intervention Before and After 9/11: Legality and Legitimacy" in Holzgrefe, J. L. and Keohane, R. O. (2003). Humanitarian Intervention: Ethical, Legal, and Political Dilemmas. Cambridge: Cambridge University Press, 53-89.

Ferris, E. G. (2011). The Politics of Protection: The Limits of Humanitarian Action. Washington DC: The Brookings Institution.

Gibney, M. J. (2004). The Ethics and Politics of Asylum: Liberal Democracy and the Response to Refugees. Cambridge: Cambridge University Press.

. (2006). A Thousand Little Guantanamos: Western States and Measures to Prevent the Arrival of Refugees. In Tunstall. K. E. (Ed.). Displacement, Asylum, Migration: the Oxford Amnesty Lectures 2004 (pp. 139-169). Oxford: Oxford University Press.

Goodwin-Gill, G. S. and McAdam, J. (2007). The Refugee in International Law. Oxford: Oxford University Press.

Haddad, E. (2008). The Refugee in International Society: Between Sovereigns. Cambridge: Cambridge University Press.

Ingram, J. D. (2008). What is a "Right to Have Rights"? Three Images of the Politics of Human Rights. American Political Science Review, 102(04), 401-416.

Isaac, J. C. (1996). A New Guarantee on Earth: Hannah Arendt on Human Dignity and the Politics of Human Rights. American Political Science Review, 90(01), 61-73.

Keohane, R. O. (2003). "Political Authority after Intervention: Gradations in Sovereignty" in Holzgrefe, J. L. and Keohane, R. O. (2003). Humanitarian Intervention: Ethical, Legal, and Political Dilemmas. Cambridge: Cambridge University Press, 275-289.

Loescher, G., Betts, A., Milner, J. (2008). UNHCR: The Politics and Practice of Refugee Protection into the $21^{\text {st }}$ Century. Abingdon: Routledge.

Nanda, V. P. (2013). The Future under International Law of the Responsibility to Protect after Libya and Syria. Michigan State International Law Review, 21(01), 1-42.

Nyers, P. (2003). Abject cosmopolitanism: the politics of protection in the anti-deportation movement. Third world quarterly, 24(6), 1069-1093.

Roberts, S. A. (2004). "The United Nations and Humanitarian Intervention” in Welsh, J. M. (Ed.). (2004). Humanitarian Intervention and International Relations. Oxford: Oxford

UNHCR. (1995). In Search of Solution, retrieved from http://www.unhcr.org/4a4c70859.html on March 29, 2015. . (2012). Displacement: The New 21 ${ }^{\text {st }}$ Century Challenge- UNHCR Global trend 2012. Geneva: UNHCR.

. (2015a). UNHCR Global Trends, Forced Displacement in 2014. Geneva: UNHCR. . (2015b). UNHCR Asylum Trends 2014 Levels and Trends in Industrialized Countires. Geneva: UNHCR.

Welsh, J. M. (2004a). "Taking Consequences Seriously: Objections to Humanitarian Intervention" in Welsh, J. M. (Ed.). (2004). Humanitarian Intervention and International Relations. 
Nurul Azizah Zayzda

Oxford: Oxford University Press, 52-68.

(2004b). "Conclusion: The Evolution of Humanitarian Intervention in International Society" in Welsh, J. M. (Ed.). (2004). Humanitarian Intervention and International Relations. Oxford: Oxford University Press, 176-188.

Zayzda, N. A., Tricesaria, A.A. I., Aziz, A. A. (2015). Refugee Protection Regime in ASEAN during the Cold War and Its Development in Post- Cold War Period in Proceeding International Conference "Bandung Conference and Beyond: Rethinking International Order, Identity, Security and Justice in a Post-Western World”. Yogyakarta: Institute of International Studies. 